\title{
CIVIL RELIGION DALAM RAJUTAN KEAGAMAAN NU
}

\author{
Chafid Wahyudi*
}

\begin{abstract}
Thebasicquestion that this papertries toanswer is isit possiblefor thevalues of different -often contending religions in a singe cantry to bethe basis for the nationhood? Or, can thevalues of a singerdiginin a cuntrywheredifferent religions exist bethebasis of thestate? Theansuer that thispaper propagatesis cetainlyna But andher questionarises What then thevalues - assuming that values area must in a sodidy or country as a tem of moral reference that mist beadoptedbyall? It istovardansweingthisquestion that thispeper isaimedat. It arguesthat reigious valuesareunivesal andmeningul for humankind Thy can serveas thebasisfor human beneit and wdl-being But thesevalues-dtenorignatedfrom different religions mist not anly beaccommodated but also bereconaled. And thereconiling concept cannd beardigion, for that wouldmen that wesupport onerdigin at theexpense of othes. Hencethis paper proposes that what has commonly been known a divil reigion bethe commongrand-thesacred cangpyasit wee in whidhvariasreligiasvaluescan beintegrated It isin other words, theintegratingmeehanismfor diffeent religiaus values, which in tum can bringthesoial and pditical hammy for all atizens. Thepaper will disass partiallarty this notionbyreferingtotheconeqt of theNahdhatul Ulama (NU) annationhoodand national identity.
\end{abstract}

Keywords: divil religion, religiausvalues, NU

\section{Pendahuluan}

Mencermati perkembangan dialektika dan hubungan antar agama di Indonesia seakan kita pada kesimpulan ekstrim, bahwa agama tidak lagi mampu melahirkan masyarakat yang harmonis, apalagi kreatif. Hal ini dapat dibuktikan dengan makin meluasnya konflik-konflik antar-intra agama dan masyarakat yang meliputi pelaku, intensitas, waktu maupun geografisnya.

Untuk menjelaskan beberapa potret tesis tersebut antara lain adalah tragedi 1 Juni 2008 di Monas (Monumen Nasional) yang menjadi saksi perekam kekerasan akibat kebencian yang meruap di setiap sudut pelataran Tugu Monas terhadap sesama anak bangsa yang bernuansa agama. Pula dengan peristiwa pelibatan agama Islam-Kristen dalam konflik Maluku. Jauh sebelumnya juga dapat disaksikan bagaimana kemenangan gerakan pro-kemerdekaan rakyat Timor-Timuryang didukung kaukus Kristen lewat Uskup Belo, G erakan Aceh Merdeka (G AM) yang didukung kaukus Islam lewat Tengku Syafi'i. Yang terakhir penyerangan terhadap komunitas Ahmadiyah di Banteng dan perusakan G ereja di Temanggung Jawa Tengah, dan mungkin ada lagi di tempat dan dalam kasus yang berbeda.

Di atas fakta-fakta ini, terasa penting memunculkan sebuah menifesto dengan mempertimbangkan gagasan aivi religion Sebuah $\mathrm{G}$ agasan yang memiliki semangat meletakkan nilai-nilai agama dan ideologi sebatas substansi, bukan formalisasi yang mengabaikan jiwa rasional. Gagasan ini juga difahami sebagai kesepakatan menimum nilai-nilai agama yang dipengangi bersama sebagai sebuah norma perekat dalam kehidupan suatu bangsa.

Ide dasar áil religionini tidak terlepas dari gagasan akan pentingnya tatanan sosial dan

*al-Fitrah Surabaya 
harmoni yang banyak dianut oleh para sosiolog Barat. Misalnya, Auguste Comte (17951857) menyatakan, "setiap masyarakat membutuhkan prinsip yang dapat mempersatukan, di mana setiap anggotanya akan hidup dalam harmoni antara satu dengan yang lainnya." Masih menurut Comte, "agama menyediakan prinsip yang menyatukan itu sebagai perekat yang akan menjamin tatanan sosial." ${ }^{1}$ Sedang Emile D urkhaim (1858-1917) menyatakan, "Bagi masyarakat yang berada dalam komposisi yang beragam dalam hal keyakinan, nilainilai, ide-ide, akan bersatu dalam satu komunitas moral tunggal yang... saling setia." Tegasnya, "selama ada orang yang hidup bersama-sama, akan ada semacam keyakinan bersama di antara mereka." ${ }^{2}$

Konsep dasar Comte dan D urkhaim di atas, mengantarkan sosiolog kenamaan asal Amerika, Robert Neely Bellah untuk memopulerkan áil reigionyang dipahami sebagai sebuah pemahaman atas pengalaman bangsa Amerika. Bellah mendefinisikan divi reigion sebagai agama publik... yang diekspresikan dalam keyakinan bersama, simbol-simbol, dan ritual... suatu penelitian asali (pada level politik) dari realitas universal dan realitas keberagamaan yang transenden... ${ }^{3}$

Gagasan áil religionitu semakin menemukan relevansinya, manakala membaca Islam di Indonesia yang sejak awal menampilkan karakter yang beragam seiring penyebaran Islam dari luar Nusantara. Sejarah mencatat, yang demikian itu memunculkan aroma konstestasi (persaingan) untuk memperebutkan klaim kebenaran. Kontestasi yang sudah terbaca dari sejarah pendirian ormas-ormas Islam di zaman kolonialisme berujung pada kontestasi baru yang beragam dengan orientasi dan ideologi baru pasca Reformasi (1998).

Di tengah-tengah kontestasi tersebut, kalangan sosial mengakui bahwa sejarah sosial Indonesia penuh dengan guratan jejak langkah NU. Pendek kata, NU merupakan salah satu kekuatan sosial penting yang ikut mewarnai formasi kebangsaan dan keislaman Indonesia. Seorang pengamat sosial, Emmanuel Subangun, membahasakan NU dengan kata-kata yang indah, "sejauh mata memandang (Indonesia) NU jualah yang nampak." 4

Tidak berlebihan jika kemudian dalam kesejarahannya, NU dianggap oleh banyak kalangan sebagai penyanggah moderasi Islam di Indonesia. ${ }^{5}$ Identitas ini akan dapat ditemukan jawabannya manakala memperhatikan fenomena bagaimana NU sebagai organisai Islam memelopori Pancasila sebagai asas tunggal di Indonesia, dan (namun) menolak penafsiran tunggal oleh pemerintah. ${ }^{6}$ Atas dasar ini pula, penerimaan NU atas Pancasila merupakan identifikasi awal dalam mengimplementasikan divil redigion Pula dengan kembalinya NU ke Khittah 1926 pada tahun 1980an yang oleh Abdurrahman Wahid dipahami

"Lewis A. Coser, "Auguste Comte 1795-1857," dalam Masters of Socidogial Thought: Idæasin Historical and Social Context(New York: Harcourt Brace Jovanovich, 1977), 3-42.

${ }^{2}$ Emile D urkheim, TheElementaryFoms of ReigionLife, trans. Karen E. Fields (New York: Collier Book, 1961), 92.

${ }^{3}$ Robert N. Bellah, BegondBeil£: Essaysof ReigioninaPost-Traditional Wordd(New York: Harper \& Row, 1970), 171 dan 179.

${ }^{4}$ Ungkapan Emmanuel Subangun ini dikutip oleh Muhammad Mustafied dari artikel pendek di kompas, namun penulisnya gagal melacak tanggal pemuatannya. Lihat Muhammad Mustafied, "Mencari Pijakan Strategi Kebudayaan NU" dalam Tashwinul Afkar, E disi No. 21 tahun 2007.112.

${ }^{5}$ Lihat Robert W. Hafner, Civil Idam IdamdanDemkratisas di Indonesia, terj. A hmad Baso, (Jakarta: ISAI bekerja sama dengan The Asia Foundation, 2001).

${ }^{6}$ Lihat D ouglas E Ramage, "Pemahaman Abdurrahman Wahid tentang Pancasila dan Penerapannya," dalam Ellyasa K H D harwis, GusDur, NU danMasjarakat Sipil(Yogyakarta: LkiS, 1994), 101. 
sebagai sebuah "pembaharuan" dan "kebangsaan". Di mana konsep tersebut diartikan oleh Ahmad Baso dengan mengejawantahkan pilar kebangsaan memperlebar pemaknaan ke-NUan sebagai bagian dari segenap komponen kebangsaan. Artinya, dalam pandangan kebangsaan ini, ke-NU-an dan keislaman bukanlah tandingan atau alternatif terhadap bangsa, tapi bagian dari komponennya yang saling menguatkan. Prinsip ukhumah wataxiiyah (persaudaraan sebangsa) melampaui ukhumah Idamiyah (persaudaraan sesama muslim).." D engan prinsip ini, pondasi aiil reigiontelah dibangun oleh NU dalam kehidupan berbangsa dan bernegara.

\section{Civil Religion: Alternatif Relasi Agama dan Negara}

G agasan divi reigiondihadirkan sebagai respon untuk menjawab tantangan yang muncul berkenaan dengan upaya-upaya sintesis teori kuno; antara teokratisme dan sekularisme. D alam teokratisme, eksistensi agama telah mengakibatkan eksistensi negara tersubordinasi, yakni fungsi agama telah dijadikan alat diskriminasi melalui instrumen negara yang berujung pada masyarakat yang tidak seagama kehilangan kebebasan religiusnya. Sedangkan sekularisme yang dalam premis prakteknya, "pemisahan agama dan politik", telah menempatkan gagasan bahwa legitimasi negara berakar pada kehendak rakyat yang tidak lagi terkait dengan religius apapun. Sehingga, kata Mark Juergensmeyer, negara yang demikian itu hanya menempatkan individu-individu diikat oleh sistem politik demokrasi yang terpusat, menyeluruh, dan tidak dipengaruhi oleh pertalian-pertalian etnik, kultural, atau religius apapun. Ikatan-ikatan itu hanya diperkuat oleh rasa emosional dari penampakan ciri wilayah geografis dan loyalitas kepada orang-orang tertentu, identitas yang menjadi bagian dari nasionalisme. ${ }^{8}$ O leh karenanya, gagasan divil reigionsebagai alternatif berkeinginan meletakkan agama dan negara dalam posisi yang sejajar, dan tidak terlalu jauh agar dapat saling bekerja sama, namun juga tidak terlalu dekat sehingga tidak saling mengkooptasi.

Menurut Phillip E. Hammond terdapat beberapa kondisi yang bisa menyebabkan munculnya agama sipil (aiil redigion): (1) kondisi pluralisme keagamaan tidak memungkinkan bagi salah satu agama untuk digunakan oleh seluruh masyarakat sebagai sumber makna general, tetapi, (2) bagaimanapun juga, masyarakat dihadapkan pada kebutuhan untuk melekatkan sebuah makna dalam aktifitasnya, khususnya ketika aktifitas itu berkaitan dengan individu dari latar belakang keagamaan. O leh karena itu (3) diperlukan sebuah sistem makna pengganti. ${ }^{9}$

D engan menempatkan diil reigion sebagai makna general bukan berarti berkehendak membinasakan agama yang telah ada, tapi sebaliknya eksistensi agama adalah pilar utama. Sebab secara individual masih memiliki agama teologisnya, tetapi dalam ranah keberagamaan, secara kolektif harus memegangi kesepakatan yang ada dalam auil reigion Sehingga yang perlu dikonkritkan adalah membedakan -bukan memisahkan- agama sebagai dogma teologis yang hanya bersemayam dalam ranah individu (private) dengan agama publik yang memiliki

${ }^{7}$ Lihat Ahmad Baso, NU Studies Pergdakan Perikiran antara FundamentalismeIdamdan LiberalismeNee-Liberal (Jakarta: Erlangga, 2006), 10-11.

${ }^{8}$ Mark Juergensmeyer, MenentangNegara SAkuler: Kdæangkitan Gldbal NasionalismeRdigus terj. Noorhaidi (Bandung: Mizan, 1998), 27.

9Phillip E. Hammond, "Bentuk-Bentuk ElementerA gama Sipil” dalam Robert N. Bellah dan Phillip E. Hammond, Vanienties of Civil Rdigion; Beragambentuk Agama Sipil dalamBeragamBentuk KdkuasaanPditik, Kultural, Ekonom, \& Sosial, terj. Imam K hoiri dkk (Yogyakarta: IRCiSoD, 2003), 186. 
semangat meletakkan substansi nilai-nilai moral agama. Ini bukan berarti pandangan transendental agama tereduksi menjadi sebuah ide yang abstrak dan terlepas dari wujud sisi kemanusiaan yang nyata. Namun, perlu perimbangan yang adil dan seimbang sebagai simbiosis mitualism

D alam implementatif praksisnya, prinsip rahmah li al-alamin dalam Islam, cinta-kasih dalam Kristian, anti kekerasan dalam Hindu, kesederhanaan dalam Budha dan lain-lain, tidak boleh menjadi prinsip teologis statis yang kemudian diterjemahkan menjadi hukum positif di Indonesia. Tetapi, pembumian norma-norma kolektif dalam bermasyarakat dan bernegara ini yang mesti disadur dari arsitektur moral substansial agama tersebut. ${ }^{10}$

Langkah di atas meniscayakan agama-agama itu bebas secara struktural maupun konseptual untuk menentukan sdf-undestandingnya. Di satu sisi negara tidak terikat dengan (salah satu) agama, ia tidak lagi mengurusi soal benar tidaknya satu atau lain agama melainkan yang menjadi urusannya adalah bagaimana konflik yang timbul dalam masyarakat dapat didamaikan. Negara menjadi penengah, tetapi ia tidak boleh mengambil atau malah memaksakan keputusan. Sikap dan peranan fungsional negara seperti ini sekaligus menjamin kebebasan keagamaan. ${ }^{11}$ D engan logika akan realitas seperti itu, tercermin dalam ungkapan Ketua Mahkamah Konstitusi Mahfud MD, "negara itu hanya bertugas melindungi rakyatnya untuk beragama, menjalankan ajaran agama. Bukan mengatur agama."12

\section{Civil Religion dalam Rajutan Tradisi NU}

1. Konstruksi NU tentang Relasi Agama dan Negara

Sebelum merumuskan posisi NU dalam kaitannya dengan relasi agama dan negara, ada baiknya mengetahui penegasan pendiri NU K.H. Hasyim Asy’ari tentang negara sebagai berikut.

"Bentuk pemerintahan Islam tidak ditentukan. Ketika yang kita hormati Nabi Muhammad meninggal dunia, beliau tidak meninggalkan pesan apapun mengenai bagaimana memilih kepala negara..., jadi, pemilihan kepala negara dan banyak lagi mengenai kenegaraan tidak ditentukan dan dapat dilaksanankan tidak terikat untuk mengikuti suatu sistem. Semua (sistem) dapat dilaksanakan pada masyarakat Islam pada setiap tempat." ${ }^{13}$

Penegasan tersebut menujukkan bahwa tidak ada ketentuan yang baku tentang bentuk negara. Dengan ujaran lain, suatu negara diberi kebebasan menentukan bentuk pemerintahannya yang selaras dengan setiap tempat, bisa demokrasi, monarkhi, teokrasi maupun bentuk lainnya. D engan berpijak pada asumsi itu, maka sedari awal NU memiliki pandangan sendiri terhadap relasi agama dan negara yang berkesesuaian dengan kondisi bangsa Indonesia. Mengenai rumusan NU tentang relasi agama dan negara, Muktamar NU pada tahun 1936 di Banjarmasin memberikan representasinya.

Pada saat itu para ulama membahas mengenai apakah negara Hindia Belanda wajib

${ }^{10}$ Chafid Wahyudi, "Misi Moral Agama yang Terabaikan", dalam Duta Massarakat(28 D esember 2009), 5.

${ }^{11}$ Olaf Schumann, "Bellah dan Wacana 'Civil Religion' di Indonesia" dalam Beyond Beif: Menemkkan Kenbali Agama Esa12" Semangat Pluralisme Beragama di Indonesia Terancam" dalam Kompes(6 O ktober 2009).

${ }^{13}$ Lukman Hakim, Pedawanan IsamKultural: Rdasi Asosiasitif Petumbuhan Civil Socidy dan Ddktrin A suaja NU (Surabaya: Pustaka Eureka, 2004), 59. 
dipertahankan jika nanti diserang oleh musuh. A tas hal itu, Muktamar memberikan putusan wajib dipertahankan dengan menempatkan Hindia Belanda sebagai Da al-Isam(negara Islam), dengan alasan mayoritas penduduknya beragama Islam dan pernah dikuasai sepenuhnya oleh orang-orang Islam. Menurut Ali Haidar, putusan seperti itu setidaknya tidak bisa lepas dari apa yang melatarinya, yakni di mana waktu itu bumi Indonesia masih dalam penjajahan Belanda (bangsa asing). O leh karenanya, hal itu -putusan Dasal-Isam sifatnya hanya sementara. ${ }^{14}$

Berangkat dari uraian di atas dapat dikatakan bahwa relasi agama (Islam) dan negara secara sederhana telah terumuskan oleh para pendiri NU sebelum bangsa Indonesia menyatakan kemerdekaannya. Wacana ini menjadi tuntas di tangan KH. Ahmad Shiddiq. Baginya, relasi antara keduanya diibaratkan "dua sisi mata uang yang berbeda, namun hakikatnya saling berhubungan dan membutuhkan; jika satu sisi dari kedua sisinya tidak ada, maka tidak dianggap sebagai sebuah koin mata uang". Mengenai hal tersebut, K.H. Ahmad Siddiq menegaskan, "D asar negara (Pancasila) dan agama Islam adalah dua hal yang sejalan dan saling menunjang. Keduanya tidak bertentangan dan tidak boleh dipertentangkan. Keduanya tidak harus dipilih salah satu dengan sekaligus membuang yang lain". ${ }^{15}$

Mendapati konstruksi NU tentang relasi agama dan negara yang demikian itu menjadikan timbul pertanyaan di mana peranan agama dalam perkara kenegaraan? Merujuk pada pertanyaan tersebut A bdurahman Wahid menulis sebagai berikut: "Islam berfungsi dalam kehidupan bangsa dalam dua bentuk. Bentuk pertama adalah sebagai etika sosial (akhlaq) warga masyarakat, sedangkan bentuk kedua adalah partikel-partikel dirinya..."16 Pada kesempatan yang lain, Abdurrahman Wahid menjelaskan, bahwa hukum Islam dalam kenyataannya hanya berlaku sebagai panduan moral yang dilakukan atas dasar kesadaran masyarakat. Sementara kebutuhan mengundangkan hukum agama hanya ada pada "apa yang dapat diundangkan saja," ${ }^{17}$ yakni pada apa yang bisa dipertimbangkan untuk berlaku bagi segenap komponen masyarakat. D engan begitu:

"Islam berfungsi bagi kehidupan masyarakat bangsa tidak sebagai bentuk kenegaraan tertentu, melainkan sebagai etika sosial yang akan memandu jalannya kehidupan bernegara dan bermasyarakat itu sesuai dengan martabat luhur dan kemuliaan derajat manusia, karena pada analisa terakhir manusialah yang menjadi obyek upaya penyejahteraan hidup itu.....Tugas Islam adalah mengembangkan etika sosial yang memungkinkan tercapainya tujuan penyejahteraan kehidupan umat manusia, baik melalui bentuk masyarakat yang bernama negara maupun di luarnya." ${ }^{18}$

Rumusan relasi agama dan negara yang diadopsi NU tersebut dengan sendirinya menegasi teori hubungan agama (Islam) dan negara dalam bingkai paradigma integralistik maupun paradigma sekularistik.

\section{Tradisi Keilmuan Keagamaan NU}

${ }^{14}$ M. Ali Haidar, Nahdatul Ulama dan Islamdi Indonesia: Pendkkatan Fikih dalamPditik (Jakarta: PT. G ramedia Pustaka Utama, 1994), 95.

${ }^{15}$ Andree Feillard, NUvisa visNegara: PencanihanIs, Betuk danMakna, terj. Lesmana (Yogjakarta: LkiS 1995), 243.

${ }^{16}$ Abdurrahman Wahid, PrismaPemikiran GusDur(Yogjakarta: LkiS, 2000), 156.

${ }^{17}$ Abdurrahman Wahid, "Islam dan Masyarakat Bangsa", dalam Pesantren, No. 3, Vol., VI, (Jakarta: 1989), 12.

${ }^{18}$ Ibid., 12-13. 
Tradisi keilmuan keagamaan yang dianut NU, sejak permulaan bertumpu pada pengertian tersendiri tentang apa yang oleh $\mathrm{NU}$ disebut dengan aqidah Ahl al-Sumah wa al-Jama'ah (Aswaja). D oktrin tersebut berpangkal pada tiga buah panutan ini: mengikuti paham al-Ash'axi dan al-Maturidiðdalam bertauhid (teologi), mengikuti salah satu mazhah

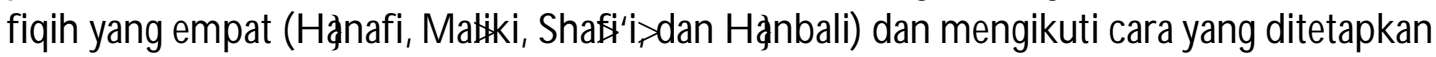
al-Junaidi al-Baghdadi dan Abu $>\mathrm{H}$ łmid al-G hazali dalam bertarekat dan bertasawuf. D engan tradisi keilmuan seperti itu, "NU mengembangkan tradisi keilmuagamaan paripurna dengan membagi siklus kehidupan para warganya dalam jumlah lingkaran kegiatan...", demikian papar Abdurrahman Wahid (G us D ur). ${ }^{19}$

G erak tradisi keilmuagamaan NU yang demikian, mengingatkan pada proyek "triepistemologi"-nya Muhł̧mmad Abid al-Jabiri dalam Naqd al-'Aql al-'Arabił $\ngtr$ Kritik Nalar Arab). Di mana al-Jabirimendapati kencenderungan epistemologi yang berlaku di kalangan bangsa Arab dan umat Islam pada umumnya, yakni kecenderungan bayari>'infari>atau burhari $\gamma^{0}$ D alam kesejarahannya, ketiganya berjalan secara pararel (sendiri-sendiri). Sementara itu, justru dalam tradisi keilmuagamaan NU, ketiganya ditempatkan ke dalam kerangka sirkulatif, bukan menegasi atau mengafirmasi satu dengan yang lain. D engan jejaring sirkulatif, meniscayakan kebenaran yang menyeluruh yang hal ini tidak akan mungkin dicapai oleh salah satunya dengan sendirinya.

D engan kerangka sirkulatif itu mengantarkan tradisi Ahl al-Summah wa al-Jama'gh memungkinkan bagi warga NU melihat sesuatu secara seimbang, harmonis dan dari berbagai tepian. Mengambil satu aspek saja dan mengabaikan aspek lainnya, jelas akan merusak tatanan kosmis yang seimbang dan harmonis ini. Pandangan doktrinal-moderat seperti inilah yang dianggap langgeng dan abadi oleh para ulama NU sebagaimana pernah ditulis oleh Abdurahman Wahid:

"Inti dari tradisi keilmuan yang dianut NU adalah perpautan organis antara tauhid, fiqih dan tasawuf secara tidak berkeputusan, yang dalam jangka panjang menumbuhkan pandangan terpautnya sendiri antara dimensi duniawi dan ukhrawi dalam kehidupan.... tradisi keilmuagamaan seperti itu sudah tentu logis kalau lalu muncul pandangan kemasyarakatan yang tidak bercorak "hitam-putih". Perpautan kedua dimensi duniawi dan ukhrawi dalam kehidupan manusia tidak memungkinkan penolakan mutlak kepada kehidupan dunia akhirat. D engan kata lain, seburuk-buruknya kehidupan dunia, ia haruslah jalani dengan kesungguhan dan ketulusan." ${ }^{21}$

Sebagai implikasi dari pandangan tradisi keilmuagamaan itu pada gilirannya akan memberikan rasa tanggungjawab dalam bersosial dan berpolitik sebagaimana diujarkan

\footnotetext{
${ }^{19} \mathrm{~A}$ bdurahman Wahid, IdamKosmqpditan: Nilai-nilai Indonesai dan Transfomasi Kdoudayaan(Jakarta: The Wahid Institute, 2007), 214.

${ }^{20}$ Tolak ukur validitas masing-masing epistemologi: Nalar bayani tergantung pada kedekatan dan keserupaan teks atau mass)dan realitas, dan nalar infariłebih kepada kematangan soial skill (empati, simpati, vestehen), sementara dalam nalar burhari ditekankan pada korespondensi, yakni kesesuaian antara rumusan yang diciptakan oleh akal manusia dengan hukum alam, dan korehensi (keruntutan dan keteraturan berpikir logis) sekaligus upaya yang terus menerus dilakukan untuk memperbaiki dan menyempurnakan temuan-temuan, rumusan-rumusan dan teori-teori yang telah dibangun dan disusun oleh jerih payah akal manusia (pragmatik). D alam perjalanan sejarahnya, ketiga model epistemologi ini pernah mencapai puncak kejayaan masing-masing. D engan epistemologi bayari>> banyak para pakar fiqih yang muncul, dengan burhari banyak filosof dan skolastik yang disegani, dan dengan infai > banyak para sufi yang istimewa dan populer.

${ }^{21}$ A bdurahman Wahid, IdamKosmpoditan, 215.
} 
oleh Gus D ur:

"Hal ini sudah tentu ada implikasinya sendiri-sendiri kepada pandangan kenegaraan yang dianut warga $\mathrm{NU}$ yang masih belum kehilangan tradisi keilmuagamaannya. Kewajiban hidup bermasyarakat, dengan sendirinya bernegara, adalah sesuatu yang tidak boleh ditawar lagi. Eksistensi negara mengharuskan adanya ketaatan kepada pemerintah sebagai sebuah mekanisme pengaturan hidup, yang dilepaskan dari perilaku pemegang kekuasaan dalam kapasitas pribadi. Kesalahan tindakan atau keputusan pemegang kekuasaan tidaklah mengharuskan adanya perubahan dalam sistem pemerintahan." 22

Konsekuensi dari pernyataan itu menempatkan kewajiban bermasyarkat, dengan sendirinya bernegara adalah mengakui keabsahan negara begitu ia berdiri dan mampu bertahan. Di sisi yang lain, penolakan sistem alternatif sebagai pemecahan masalah yang dihadapi suatu bangsa yang telah membentuk negara. Sebaliknya, cara-cara yang digunakan dalam melakukan perbaikan keadaan senantiasa bercorak gradual. Pandangan ini sesuai dengan penjelasan K.H. Ahmad Siddiq (1926-1991) tentang kehidupan bernegara, yakni:

a) Negara nasional (yang didirikan bersama oleh seluruh rakyat) wajib dipelihara dan dipertahankan eksistensinya.

b) Penguasa negara (pemerintah) yang sah harus ditempatkan pada kedudukan yang terhormat dan ditaati, selama tidak menyeleweng, dan/ atau memerintah ke arah yang bertentangan dengan hukum dan ketentuan Allah.

c) Kalau terjadi kesalahan dari pihak pemerintah, cara memperingatkannya melalui tatacara yang sebaik-baiknya. ${ }^{23}$

Berpijak pada pandangan di atas, maka ajaran Ahl al-Sumnah wa al-Jama'ah yang menjadi pilar keilmuagamaan NU mendasari adanya pertimbangan kemaslahatan. Atas dasar itu, menolak konflik dan cenderung adaptif adalah manifestasi dari ajaran $\mathrm{Ahl}$ alSunnah wa al-Jamałh sebagai sikap dalam membangun masyarakat dan negara. Di sisi yang lain, meletakkan Ahl al-Sunmah ua al-Jama'ah sebagai tataran relegiusitas dalam bernegara menjadikan watak NU sebagai organisasi bersifat terbuka, fleksibel dan adaptif. Maka atas dasar itu, dapat dipahami jika kemudian NU menerapkan penerimaan (baca: taat) terhadap negara RI yang berdasarkan Pancasila.

Penerimaan itu mengantarkan Ahl al-Sunnah wa al-Jama'gh pada pengertian bahwa ajaran-ajaranya bisa menjadi faktor integrasi dan kontrol bangsa yang pada gilirannya menjadi basis solidaritas sosial yang kuat. Hal itu tercermin pada konsep mempertahankan negara atas dasar kemaslahahatan, di sisi lain mampu menjadi kontrol dengan melakukan perbaikan dengan cara yang gradual.

\section{Peranan NU dalam Memotivasi Civil Religion di Indonesia}

1. Rumusan Konstitusi 1945: Merajut Keberagamaan dalam Bernegara

Pada masa akhir kolonialisme, muncul perdebatan mengenai konstitusi (dasar) negara. Sebagaian mereka ada menginginkan agar dasar negara Indonesia adalah Islam,

${ }^{22}$ Ibid., 216.

${ }^{23 K}$.H.A chmad Siddiq, KhittahNahdiyyah(Surabaya: Khalista bekerjasama dengan Lajnah Ta'lif Wan Nasyr Jawa Timur, 2006), 66. 
sementara yang lain menghendaki agar dasar negara Indonesia nasionalis (sekuler). Perdebatan tentang dasar negara mulai memanas pada bulan-bulan menjelang proklamasi kemerdekaan Indonesia, 17 Agustus 1945. Di tengah perdebatan tentang bentuk dasar negara itu, pada tanggal 1 Juni 1945, Soekarno berupaya mengatasi persoalan tersebut dengan mengajukan "lima dasar" atau Pancasila sebagai landasan filosofis Indonesia. ${ }^{24}$

Rumusan awal Pancasila tidak dengan serta-merta diterima, khususnya kalangan Islam. D engan melihat eksistensi kepentingan politik Islam sekaligus juga kemajemukan agama di Indonesia, Soekarno membentuk panitia yang kemudian secara kompromis menghasilkan Piagam Jakarta ${ }^{25}$ yang di dalamnya termaktub kalimat; "Ketuhanan dengan kewajiban menjalankan syariat Islam bagi pemeluknya" - dikenal dengan tujuh kata-. Namun, langkah kompromis lewat Piagam Jakarta itu kemudian memunculkan ketegangan baru antara pusat dan Indonesia bagian Timur yang kebanyakan non-muslim. Mereka keberatan dan mengancam akan ke luar bila Piagam Jakarta dijadikan dasar negara. Sebab, dikhawatirkan nantinya kata "shari §h" akan menimbulkan masalah bagi agama lain maupun adat-istiadat.

Sesaat setelah proklamasi kemerdekaan pada tanggal 18 Agustus 1945, Moh Hatta memanggil empat anggota Panitia Persiapan Kemerdekaan yang dianggap mewakili Islam: Ki Bagus Hadikusomo, Kasman Singodimedjo, Teuku Muhammad Hasan dan Wahid Hasyim. D emi menjaga keutuhan bangsa pada saat-saat genting ini, mereka setuju untuk merevisinya. Sebagai gantinya Wahid Hasyim mengusulkan agar Piagam Jakarta diganti dengan rumusan "Ketuhanan Yang Maha E sa" ${ }^{26}$ yang semula hanya "Kepercayaan kepada Tuhan". ${ }^{27}$

Di situlah letak pemikiran yang ulung dari kader NU, Wahid Hasyim yang mampu mengakomodir keberagamaan di dalam satu negara. Bagi umat Islam, arti yang penting inti dari sila pertama tentang kepercayaan terhadap "Tuhan Yang Maha Esa" adalah menifestasi aqidah Islam. D engan penerimaan Pancasila yang demikian, merupakan pelaksanaan secara nyata ajaran-ajaran shar'ah sesuai dengan cita-cita Islam. Di sisi yang lain adalah tidak sepenuhnya benar jika kepercayaan terhadap "Tuhan Yang Maha Esa" berimplikasi tidak terdapat pada agama lain sebagaimana dikemukakan D eliar Noer ${ }^{28}$ yang kemudian kerap dikutip oleh penulis-penulis berikutnya seperti Andree Feillard, Robert W. Hafner, dan lain-lain.

\footnotetext{
${ }^{24}$ Menurut Andree Feillard, Pancasilayang diajukan Soekarno terdapat peranan ununrenbukdari tiga tokoh kenamaan muslim, Kiai Wahid Hasyim, Kiai Maskur - keduanya dari NU- dan Kiai Kahar Muzakkar - dari PII- , Mengenai proses unn-renbugtentang Pancasila itu merupakan kesaksian lisan dari Kiai Maskur, yang pernah menjabat menteri agama pada tahun 1946-1949, serta komandan pasukan Sabilillah serta ikut pula dalam diskusi panitia tersebut. D ata tersebut diperoleh oleh Andree Feillard dari A rsip Nasional Indonsia dalam bentuk kaset yang merekam wawancara dengan Kiai Masykur. Menurut Feillard, data tersebut belum sama sekali diterbitkan oleh para peneliti. Lihat Andree Feillard, NUvisa uisNeegra, 32-35.

${ }^{25}$ Piagam Jakarta adalah dokumen yang dimaksudkan untuk dijadikan sebagai preambule(pembukaan) undangundang dasar bagi Negara Indonesia yang akan dibentuk. D okumen ini ditandatangani oleh sembilan tokoh nasional di Jakarta pada tanggal 22 Juni 1945. mereka adalah Soekarno, Muhammad Hatta, A.A. Maramis, Abikusno Tjokrosujoso, Abdul Kadir Muzakir, H. Agus Salim, Mr. Ahmad Subardjo, Wahid Hasyim dan Muhammad Yamin. Lihat Umar Basalim, ProKantraPiagamJakartadi EraRfomas (Jakarta: Pustaka Indonesia Satu, 2002), 37-38.

${ }^{26}$ Andree Feillard, NUvisa visNegara, 38-39.

${ }^{27}$ Lihat Robert W. Hafner, Civil Isam 85-86.

${ }^{28}$ D eliar Noer, "Muhammad Hatta: Biografi Politik" dalam Andree Feillard, NU visa uisNegra, 39.
} 
Sebab secara teoritis, semenjak ribuan tahun yang lalu masyarakat sudah percaya akan adanya satu kekuatan gaib yang melampau kekuatan manusia. Kekuatan gaiblah itulah yang dipahami sebagai Tuhan. Pemahaman terhadap satu kekuatan gaib itu yang kemudian disimbolisasikan ke dalam benda-benda di alam sekitarnya. Benda-benda itu dianggap sebagai Tuhan yang hadir ke dunia. Tuhan kemudian dimengerti dapat menampakkan diri-Nya dalam berbagai rupa di alam raya ciptaan-Nya yang disebut; tajalli al-shuhud (penampakan diri). Penampakan diri Tuhan yang tertinggi ada pada makhluq ciptaan-Nya yang berwujud manusia, demikianlah Muhyiddin Ibnu A rabi berfilsafat dalam dunia mistiknya. Oleh karena itu, agama selain Islam juga 'menyembah' yang Esa (œrmonteisme. ${ }^{29}$

Keputusan Wahid Hasyim menggugurkan Piagam Jakarta setelah sebelumnya dia pertahankan, menurut Andree Feillard menunjukkan fleksibilitas (sikap lentur) seorang Wahid Hasyim. ${ }^{30}$ Bahkan masih menurutnya, dalam pristiwa itu, NU yang diwakili Wahid Hasyim bersedia mencari jalan lain dengan agama lainnya demi persatuan bangsa. ${ }^{31}$ Dikatakan pula, bahwa mendasari alasannya untuk menanggalkannya adalah sebentuk "pemahanan yang relatif leberal terhadap Piagam Jakarta" ${ }^{32} \mathrm{Hal}$ ini tercermin dalam penjelasannya sebagimana dilangsir Feillard dari Saifuddin Zuhri: ${ }^{33}$

"Pertama, situasi politik dan keamanan dalam permulaan Revolusi memang memerlukan persatuan dan kesatuan bangsa. Kedua, sebagai golongan minoritas mereka memang dapat melakukan politik ofensif bahkan disertai tekanan politik (dantage) seolaholah ditindas oleh golongan mayoritas. Sebagai golongan yang paling berkepentingan

\footnotetext{
${ }^{29}$ Kepercayaan monoteisme dasar (oer-monoteisme) akan eksistensi Tuhan yang tunggal sebenarnya sudah muncul pada masyarakat yang paling primitif (kuno) sekalipun, Lihat Syamsuddin Abdullah, Agama dan Masyarakat: PendkatanSosidog A gama(Jakarta: Logos Wacana Ilmu, 1997), 28. A da baiknya untuk membuktikan ke-E sa-an agama-agama di Indonesia akan dipaparkan secara singkat dalam tulisan ini. Bagi agama Kekuatan gaib itu tunggal yang disebut Sang Hyang Widi Wasa yang terpancar ke dunia dalam bentuk tiga dewa dengan istilah Trimurti. Tuhan Yang Maha E sa atau Ida Hyang Widi Wasa tentulah bersifat tunggal. Lebih jauh dalam doa Trisadnya (rumusan tiga pokok doa umat Hindu) dalam bait ke-2, misalnya kalimat terakhir di situ disebutkan kata Sansekerta "nadwhya" mengandung arti hanya satu tidak ada dua Tuhan. Hal demikian menunjukkan bahwa agama Hindu juga menyembah satu Tuhan atau monoteistis, meskipun dipuja dengan banyak manifestasi, seperti Brahmana, Wisnu dan Siwa. Sebagaimana agama Hindu, Buddha mempercayai adanya Tuhan Yang Maha Esa. Semua sekte Budha menyebut Tuhan Yang Maha Esa dengan sebutan yang berbeda-beda tetapi pada hakekatnya adalah satu. Untuk menyebut Tuhan Yang Maha Esa masyarakat Budha menyebut Paramita Budha, ada pula yang memanggil Sanghyang Adi Budha, atau Hyang Tathagata yang semuanya itu mencerminkan yang esa. Jadi walaupun sebutan itu beraneka macam tetapi pada hakekatnya Tuhan itu dimaknai esa adanya. D emikian pula dengan agama Katolik dan Protestan, sekalipun agama ini secara eksplisit mengukuhkan dokma trinitasnya yang seringkali berseberangan keras dengan tafsiran monoteistik Islam. Di dalam agama Kekristenan Tuhan dipahami tidak sekadar transenden, melainkan juga immanen, Ia ada di dalam dunia. Imnanensi Tuhan ini diwujudkan melalui tindakan Tuhan guna menyelamatkan manusia atau dalam kredonya yang eksklusif disebut dengan; thebdieein GodtheFatherAlmighty, Maker of heavenandearth: AndinJesusChrist, hisonlySon, arLard Jadi IsaAl-masih ini merupakan tindakan immanensi Tuhan yang dalam istilah teologi sering disebut dengan konsep Allah yang berinkarnasi. Jadi kedua agama ini juga memiliki kepercayaan kepada satu Tuhan (oneultimate. Yang ultimate inilah yang dipahami pemeluknya melalui K ristus sebagai Tuhan yang memancarkan kasih kepada segenap manusia. Lihat Shofiyullah, "Transformasi Tawhid dalam Agama-Agama Historis" dalam http:// shofiyullah.wordpress.com/ 2008/ 05/ 31/ transformasi-tawhid-dalam-agama-agama-historis/ . (16 Juli 2010)

${ }^{30}$ Andree Feillard, "Nahdlatul Ulama dan Negara: Flksielitas, Legitimasi dan Pembaharuan" dalam (ed.) Ellyasa KH. D harwis, GusDur, NU danMasyarakat Sipil (Yogyakarta: LkiS, 1994), 7.

${ }^{31}$ Andree Feillard, NU visa uisNegra, 40.

${ }^{32}$ Andree Feillard, "Nahdlatul Ulama D an Negara" , 8.

${ }^{33}$ Andree Feillard, NUvisavisNegara, 40-41.
} 
tergalangnya persatuan dan kesatuan dalam menghadapi Belanda yang masih mempunyai kaki tangan di mana-mana, para pemimpin Islam dan nasionalis memenuhi tuntutan mereka. D engan pengertian: Bahwa kewajiban menjalankan sharisat Islam bagi pemelukpemeluknya akan dapat ditampung dalam melaksanakan fasal 29 ayat 2 UUD '45 secara jujur yaitu ayat yang berbunyi: Negara menjamin kemerdekaan tiap-tiap penduduknya untuk memeluk agamanya masing-masing dan untuk beribadat menurut agama dan kepercayaan itu."

Kata "kemerdekaan" dalam pasal 29 UUD itulah yang dipandang Feillard, bahwa Wahid Hasyim memberikan penafsiran leberal terhadap kata "kewajiban" yang terdapat dalam Piagam Jakarta yang kabur batasannya, di samping ditakuti beberapa kalangan akan dipaksakan Islam. ${ }^{34}$ Singkatnya, Wahid Hasyim, putra pendiri NU, terlihat memegang teguh dua prinsip utama yang tercantum di dalam Undang-Undang D asar; petama, kebebasan mutlak beragama, dan keelua monoteisma (keesaan).

Penetapan konstitusi negara seperti itu menjadikan Indonesia tidak murni menjadi negara sekuler tapi juga tidak menjadi negara Islam. Sebaliknya, Indonesia memperkenalkan dirinya sebagai negara Pancasila dengan menempatkan semua pemeluk agama dalam posisi yang sama. Semua warga dalam bernegara berhak menjalankan agamanya dan beribadah sesuai dengan agama dan kepercayaannya. Negara yang demikian dirembesi -meminjam konsep aivi redigion Robert N. Bellah-suatu yang asali dari realitas universal dan realitas keberagamaan yang transenden... (grnime apprehension of universal and trancendent religias relity......35

2. Khittah 1926: Penerimaan Pancasila sebagai Asas Tunggal

Keputusan pemerintah (Orde Baru) menjadikan Pancasila menjadi sebagai asas ideologis - gagasan itu muncul tanpa ditegaskan sebagai asas tunggal atau bukandimunculkan pada tahun 1966 sebagai alat pemersatu bangsa atas saran Angkatan Bersenjata. Namun saran tersebut gagal terlaksana. ${ }^{36}$ Upaya tersebut tidak berhenti, Presiden Soeharto dalam pidato kenegaraan 16 Agustus 1982 di hadapan MPR, menyatakan bahwa seluruh kekuatan politik harus menerima Pancasila sebagai satunyasatunya asas. Pandangan tersebut kemudian mendapatkan legitimasi pada tahun 1983 melalui keputusan SU-MPR ${ }^{37}$ yang dimantapkan pada tahun 19 Perbruari 1985. D engan persetujuan D PR mengeluarkan Undang-Undang No. 3/ 1985 yang menetapkan partaipartai politik dan Golkar harus menerima Pancasila sebagai asas tunggal. Kebijakan itu dilanjutkan dengan dikeluarkannya Undang-Undang No. 8/ 1985 pada tanggal 17 Juni 1985. Undang-undang ini menetapkan bahwa seluruh organisasi sosial atau massa harus mencantumkan Pancasila sebagai asas tunggal. ${ }^{38}$

Berkenaan dengan asas tunggal Pancasila, NU sedari awal dengan kesadaran, bukan koersif atau hegemoni mampu mengakomodirnya sebagai pemaknaan dalam kehidupan berbangsa dan bernegara. Kesadaran itu tentu didukunganya dengan argumentasi-

${ }^{34}$ Ibid., 41. dan Andree Feillard, "Nahdlatul Ulama dan Negara", 8.

${ }^{35}$ Robert N. Bellah, BeyondBdie: Essays of Rdigion, 171 dan 179.

${ }^{36}$ Andree Feillard, NUvisavisNegara, 233-234.

${ }^{37}$ A sep Saiful Muhtadi, Kommikas Pditik Nahdatul Ulama: Pegulatan Penikiaran Pditik Radikal danAkomodatif (Jakarta: LP3E S, 2004), 137.

${ }^{38} \mathrm{~K}$ hamami Z ada, IdamRadikal: Pergulatan OrmasOrmasIdamGanisKerasdi Indanesia. (Jakarta: Teraju, 2002), 42. 
argumentasi rasional yang disandarkan pada alasan tedogisnmmatifkeagamaan NU. Bahkan kesadaran itu juga berbuah sikap kritis manakala Pancasila sebagai asas tunggal mengalami interpretasi tunggal seperti yang terjadi pada tahun 1975 dan 1978 di mana NU menolak terhadap penataran ideologi Pancasila (P4). ${ }^{39}$

Sikap penerimaan NU terhadap asas tunggal Pancasila setidaknya merupakan kontinuitas terhadap pilihan dasar negara semenjak dikukuhkan pada 18 Agustus 1945. G uratan jejak langkahnya tercatat untuk mengawal eksistensi Pancasila, meski pada ruangruang tertentu harus diakui jejak langkahnya terkadang berkelok dengan hasrat untuk penegakan hukum Islam seperti yang terjadi pada perdebatan konstitusi 1956-1959 bersama Masyumi dan partai politik Islam lainnya. ${ }^{40}$

Hasrat untuk membangkitkan Piagam Jakarta kembali terjadi pada tahun 1966 bersama-sama komunitas Islam yang lain. Dalam kasus ini tentunya harus dipahami, bahwa motif yang melatarbelangi adalah perlawanan terhadap kaum nasionalis komunis dan sekuler yang berusaha meneggelamkan agama. Pada kesempatan itu, tokoh NU Kiai D achlan yang menjabat sebagai Menteri Agama menyatakan, "orang-orang yang menentang Piagam Jakarta sebagai munafik. ${ }^{41}$ D ua tahun berikutnya, pada tahun 1968 hasrat itu luntur, NU mengubah arah dengan kembali memberi dukungan penuh pada negara Pancasila. ${ }^{42}$

Bisa jadi -baca: kembali memberi dukungan penuh terhadap Pancasila-, meruntut kesejarahan yang tertuang dalam catatan Sidney Jones sebagaimana dikutip Robert W. Hefner tidak lepas dari upaya K.H. Ahmad Siddiq yang pada awal 1957 menulis artikel yang menyatakan Islam tidak membutuhkan berdirinya negara Islam. Sebaliknya umat Islam menerima prinsip pluralisme yang tertuang dalam Pancasila. ${ }^{43}$

D alam artikel tersebut, K.H. A hmad Siddiq menginginkan, "kesamaan wawasan kemasyarakatan", karena Islam "mengakui adanya kelompok manusia, bangsa, suku, kabilah dan sebagainya." Menurutnya, "satu sama lain harus saling mengenal dan mengakui eksistensinya masing-masing, tidak boleh yang satu menghapus eksistensi yang lain." Perkembangan dan pertumbuhan kelompok harus secara wajar. ${ }^{44} \mathrm{~A}$ tas dasar pluralis itulah K.H. Ahmad Siddiq mempertahankan Pancasila yang sudah dirilis oleh NU pada saat kemerdekaan. O leh karena itu, K.H A hmad Siddiq memandang penerimaan Pancasila ansich mestinya tidak menimbulkan persoalan, karena NU telah ikut menyusun UndangUndang Dasar 1945 dan dengan demikian berarti menerima Pancasila, bukan sebagai "taktik", melainkan karena NU benar-benar percaya terhadap universalitas prinsip-prinsip ideologi Pancasila. ${ }^{45}$

Ide dasar K.H. Ahmad Siddiq tentang penerimaan Pancasila tersebut kemudian dipresentasikan sekaligus diformalkan pada Musyawarah Nasional (Munas) Alim Ulama NU di Situbondo tahun 1983 yang kemudian menjadi acuan bagi keputusan Munas yang

${ }^{39}$ Andree Feillard, NUvisavisNegara, 234.

${ }^{40}$ Robert W. Hafner, Civil Isam 172.

${ }^{41}$ Ibid., 166-167.

${ }^{42}$ Selain motif seperti paparan di atas, gerak NU yang demikian juga ditenggarai adanya konfrontasi dengan

Pemerintah khususnya dari militer. Lihat Ibid., 165-168.

${ }^{43}$ Ibid., 163.

${ }^{44}$ Andree Feillard, NUvisavisNegara, 251.

${ }^{45}$ Ibid., 244. 
melahirkan deklarasi tentang hubungan Islam dengan Pancasila (negara) yang berisi:

1. Pancasila sebagai dasar dan falsafah negara Republik Indonesia bukanlah agama, dan tidak dapat menggantikan kedudukan agama.

2. Sila ketuhanan Yang Maha Esa sebagai dasar negara Republik Indonesia menurut pasal 29 ayat (1) UUD 1945, yang menjiwai sila-sila yang lain, mencerminkan tauhid menurut pengertian keimanan dalam Islam.

3. Bagi Nahdlatul Ulama, Islam adalah aqidah dan shari $\Varangle t$, meliputi aspek hubungan manusia dengan Allah dan hubungan antar manusia.

4. Penerimaan dan pengamalan Pancasila merupakan perwujudan dari upaya umat Islam Indonesia untuk menjalankan sharist agamanya.

5. Sebagai konsekuensi dari sikap di atas, Nahdlatul Ulama berkewajiban mengamankan pengertian yang benar tentang Pancasila dan pengalamannya yang murni dan konsekuen oleh semua pihak. ${ }^{46}$

Keputusan Munas Alim Ulama NU tentang penerimaan Pancasila itu kemudian dikukuhkan dalam Muktamar NU ke-27 di Situbondo pada tahun 1984. Pada kesempatan itu (baca: Muktamar) pula, K.H. A hmad Siddiq menambahkan, bahwa hubungan-hubungan yang mempersatukan Republik Indonesia (negara) dengan Umat Islam (agama) adalah pencantuman keesaan Tuhan dalam sila pertama Pancasila dan kalimat "dengan rahmat Tuhan Yang Maha Kuasa" dalam mukaddimah Undang-Undang D asar 1945, menunjukkan sifat religius kehidupan berbangsa Indonesia ${ }^{47}$ D engan begitu, maka nilai-nilai Pancasila telah menjembatani bentuk negara antara negara sekuler dan negara agama. D engan kata lain, Pancasila mejadikan identitas sebuah negara yang religius karena disadur dari nilainilai agama.

Penerimaan asas tunggal Pancasila menjadi bahasa bersama dalam bernegara menjadi sangat sigifikan bagi NU, tatkala pada Munas Alim Ulama di Cilacap Jawa Tengah pada tahun 1987, secara berilian K.H Ahmad Siddiq membuat para ulama dan bangsa Indonesia untuk menentang fanatisme keagamaan. D alam sebuah teks yang berjudul, "Ukhuwah Islamiyah dan Kesatuan Nasional: Bagaimana Memahami dan Menerapkannya", K.H. Ahmad Siddiq meletakkan dasar solidaritas umat Islam terhadap umat lain. Menurutnya, dalam Islam, ukhuwah mencakup tiga varian; ukhumah Islamiyah (persaudaraan sesama muslim), ukhumah vatäriyah (persaudaraan sebangsa) dan ukhwah bashaniyah (persaudaraan sesama manusia)..$^{48}$

Paska Khittah 1926, penerimaan atas Pancasila sebagai asas tunggal kembali dikumandangkan NU pada rapat Akbar pada tanggal 1 Maret 1992 di Stadion Senayan Jakarta, berlangsung dalam acara peringatan hari lahir NU yang ke-66. Sang pemrakarsa rapat, Abdurrahman Wahid waktu merasa perlu mengadakan Rapat Akbar, karena NU mengamati masih kuat tendensi sektarianisme dan eksklusifisme di masyarakat. ${ }^{49}$ Melalui rapat itu, NU menegaskan kepada semua pihak komitmen kebangsaannya. Pada saat yang

\footnotetext{
${ }^{46} Z$ udi Setiawan, NasionalismeNU (Semerang: Aneka Ilmu, 2007), 136-137,

${ }^{47}$ Andree Feillard, NUvisavisNegra, 246.

${ }^{48}$ Ibid., 376.

${ }^{49}$ Einar M. Sitompul, "NU, Asas Tunggal Pancasila dan Komitmen Kebangsaan: Refleksi Kiprah NU Pasca K hitta 26" dalam (ed.) Ellyasa KH. D harwis, GusDur, NU danMasjarakat Sipil (Yogyakarta: LkiS, 1994), 97.
} 
sama Abdurahman Wahid ingin menciptakan momentum politis, bahwa sekarang umat Islam khususnya NU telah memasuki era baru, yakni fase untuk mengamalkan nilai-nilai Islam dalam konteks persatuan dan kesatuan bangsa serta transformasi sosio-kultural. ${ }^{50}$

A pa yang diwujudkan NU selama rentang sejarah tentang komitmen kebangsaan dengan memanggul kesetian pada asas tunggal Pancasila, tidak hanya sekedar menjadi kekuatan politik yang berkiprah untuk diri sendiri atau hanya menjadi pendukung kebijakan pemerintah. Akan tetapi komitmen itu merupakan conem terhadap kehidupan berbangsa dan bernegara agar nilai-nilai keagamaan tetap menjadi acuan kehidupan bangsa.

\section{Penutup: Etika Publik sebagai Keberagamaan NU}

Sebagaimana diketahui konsep divil religion menginginkan tampilnya agama pada aras nilai moral atau etika untuk mewujudkan makna general di dalam kehidupan berbangsa dan bernegara. Dengan menggambarkan keagamaan NU melalui hasil pembacaan dari konsep avil religion, maka, penulis mencoba memunculkan istilah "etika publik" sebagai keberagamaan NU.

Istilah "etika publik" adalah merujuk pada pengertian yang telah disarikan dari gagasan divi reigion tentang nilai-nilai atau moralitas agama yang telah mengalami transformasi dari ruang privat yang primordial dan komunal ke wilayah yang terbuka dan rasional. D engan ujaran lain, menempatkan agama sebagai etika yang bermain dalam publik. Maka agama tidak sekedar bermakna pengakuan terhadap nilai-nilai spiritual dan transedental, namun turut mengisi dunia publik seperti politik dan ekonomi sebagaimana tersirat dalam pernyataan Jose Casanova:

".....agama telah "terpublikasikan" dalam dua pengertian. Ia masuk ke "dunia publik" dan oleh karena itu mencapai "publisitas". Berbagai hal yang bernuansa "publik" - media massa, ilmu-ilmu sosial, politisi profesional, dan "publik secara keseluruhan"- serta merta memberikan perhatian kepada agama. Ketertarikan publik yang tak terduga itu berangkat dari kenyataan bahwa agama, dengan tidak lagi menyerahkan urusannya pada lingkup privat, berarti telah mempercayakan dirinya pada arena moral dalam konteks politik. ${ }^{51}$

Hadirnya catatan Casanova tersebut, dengan sendirinya menjadi bentuk antitesis terhadap teori sekulerisasi yang membawa konsekuensi pada tersingkirnya agama ke ruang privat dan bahkan berakhirnya agama. Sebaliknya, kehadiran agama dalam ruang publik mesti dipahami dalam kerangka nilai-nilai etis dan moralnya.

Sementara merujuk pada inti dari tradisi keilmuan yang dianut NU, secara epistemis terbukti mampu menampilkan proses universalisasi ajaran-ajaran agama menjadi bahasa etika. D engan epistemis itu, terlihat jelas bahwa keagamaan NU tidak berkepentingan dengan manifestasi formalisasi agama. Kenyataan tersebut sesuai dengan apa yang diungkapkan KH. Sahal Mahfudz dalam pernyataan sikap NU pada saat khutbah iftitah Munas Alim Ulama dan Konbes NU di Sukolilo Surabaya, 28 Juli 2006:

"NU juga sejak awal mengusung ajaran Islam tanpa melalui jalan formalistik, lebihlebih dengan cara membenturkannya dengan realitas secara formal, tetapi dengan cara lentur.

50Ibid., 97-98.

${ }^{51}$ Jose Casanova, "Pendahuluan" dalam Agama Publik di Dunia Modkm terj. Nafis Irkham (Surabaya: Pustaka Eureka, 2003), xii. 
NU berkeyakinan bahwa syari'at Islam dapat diimplementasikan tanpa harus menunggu atau melalui institusi formal. NU lebih mengidealkan substansi nilai-nilai syari'ah terimplementasi di dalam masyarakat ketimbang mengidealisasikan institusi. Kehadiran institusi formal bukan suatu jaminan untuk terwujudnya nilai-nilai syari'ah di dalam masyarakat." 52

D ari pernyataan tersebut tanpak bahwa NU ketika bermain di ruang publik dalam arti bermasyarakat dan bernegara lebih mengidealkan transformasi etika. Sementara nilai etika itu pada hakikatnya merupakan sublimasi dari shari ‘h agama>Meminjam penjelasan Soejatmoko, "patokan-patokan tentang nilai makna dan moralitas itu ternyata berakar dari agama (Soejatmoko, 1984: 203). D engan begitu keagamaan NU merambah kakinya di ruang publik dalam semangat kemanusiaan melalui pengejawantahan rahmhah li al-'alamin yang aplikasi etisnya adalah hidup bersama sebagai bangsa dengan pemenuhan misi perdamaian atas semua orang. Pesan-pesan moral substansial agama inilah yang kemudian tersublimasi menjadi norma-norma kolektif dalam pengertian divil reigion Pada konteks inilah maka NU mampu membangun ketulusan kerja dengan menembus lintas batas - tanpa sekat formalitas agama-, baik kerja sama ukhumah Islapiyah (persaudaraan sesama muslim), ukhumah watakiijah (persaudaraan sebangsa) dan ukhwah bashariyah (persaudaraan sesama manusia).

\section{Daftar Rujukan:}

Abdullah, Syamsuddin. Agama dan Masyarakat: Pendkatan Sosidog Agama. Jakarta: Logos Wacana Ilmu, 1997.

Basalim, Umar. Pro Kontra PiagmmJakarta di Era Refomasi. Jakarta: Pustaka Indonesia Satu, 2002.

Baso, Ahmad. NU Studies: Pergolakan Pemikiran antara Fundamentalisme Islam dan Liberalisme Neo-Liberal. Jakarta: Erlangga, 2006.

Bellah, Robert N. BegondBdif: Essays of Rdiginina Post-Traditional Wodd New York: Harper \& Row, 1970.

Casanova, Jose. "Pendahuluan" dalam Agama publik d Dunia Modkm terj. Nafis Irkham. Surabaya: Pustaka Eureka, 2003.

Coser, Lewis A. "Auguste Comte 1795-1857," dalam Mastes of Soidogical Thaught: Idæes in Histarical and Social Context. New York: Harcourt Brace Jovanovich, 1977.

D urkheim, emile. TheElementary Foms of Reigin Life, trans. Karen E. Fields. New York: Collier Book, 1961.

Feillard, Andree. NU vis a vis Negara: Pencarihan Isi, Bentuk dan Makna, terj. Lesmana. Yogjakarta: LkiS 1995.

. "Nahdlatul Ulama dan Negara: Flksielitas, Legitimasi dan Pembaharuan" dalam (ed.) Ellyasa KH. D harwis, Gus Dur, NU dan Masyarakat Sipil. Yogyakarta: LkiS, 1994.

\footnotetext{
52" Mengkonversi Sistem Pemerintahan: Pengantar Diskusi Seputar Khilafah" dalam http:// c orpusali enum.multiply. com/journal/i tem/164/ Pengantar D iskusi Khilafah KH Muhyidin_Abdusshomad Ketua PCNU_Jember (diposting 2 November 2007. Diunduh $16 \bar{A}$ gustus 20̄08)
} 
Hafner, Robert W. Civil Islam: Islam dan D emokratisasi di Indonesia, terj. Ahmad Baso. Jakarta: ISAI bekerja sama dengan The Asia Foundation, 2001.

Hakim, Lukman. Perlawanan Islam Kultural: Relasi Asosiasitif Pertumbuhan Civil Society dan D oktrin Aswaja NU. Surabaya: Pustaka Eureka, 2004.

Haidar, M. Ali. Nahdlatul Ulama dan Islam di Indonesia: Pendekatan Fikih dalam Politik. Jakarta: PT. Gramedia Pustaka Utama, 1994.

Hammond, Phillip E. "Bentuk-Bentuk Elementer Agama Sipil" dalam Robert N. Bellah dan Phillip E. Hammond, Varienties of Civil Reigion: Beragambentuk Agama Sipil dalam Beragam Bentuk Kdkuasaan Pditik, Kultural, Ekonom, \& Sosial, terj. Imam Khoiri dkk. Yogyakarta: IRCiSoD, 2003.

http:// corpusalienum.multiply.com/journal/item/164/ Pengantar_Diskusi_Khilafah_KH_Muhyidin_Abdusshomad_Ketua_PCNU_Jember diposting 2 November 2007. D iunduh 16 Agustus 2008).

Juergensmeyer, Mark. Menentang Negara Sekuler: Kebangkitan G lobal Nasionalisme Religus, terj. Noorhaidi. Bandung: Mizan, 1998.

Muhtadi, Asep Saiful. Komunikasi Politik Nahdlatul Ulama: Pergulatan Pemikiaran Politik Radikal dan Akomodatif. Jakarta: LP3E S, 2004.

Mustafied, Muhammad. "Mencari Pijakan Strategi Kebudayaan NU" dalam Tashinil Afkar, Edisi No. 21 tahun 2007.

Noer, D eliar. Muhammad Hatta: Biografi Pditik. Jakarta: LP3E S, 1990.

Ramage, D ouglas E. "Pemahaman Abdurrahman Wahid tentang Pancasila dan Penerapannya," dalam Ellyasa KH D harwis, Gus Dur, NU dan Masyarakat Sipil. Yogyakarta: LKiS, 1994.

Setiawan, Zudi. Nasinalisme NU. Semerang: Aneka Ilmu, 2007.

Sitompul, Einar M. "NU, Asas Tunggal Pancasila dan Komitmen Kebangsaan: Refleksi Kiprah NU pasca Khitta 26" dalam (ed.) Ellyasa KH. D harwis, Gus Dur, NU dan Masyarakat Sipil. Yogyakarta: LKiS, 1994.

Siddiq, KH. A chmad. Khittah Nahdiyyah Surabaya: Khalista bekerjasama dengan Lajnah Ta'lif Wan Nasyr Jawa Timur, 2006.

Shofiyullah. "Transformasi Tawhid dalam Agama-agama Historis" dalam http:// shofiyullah.wordpress.com/ 2008/ 05/ 31/ transformasi-tawhid-dalam-agama-agamahistoris/ . (16 Juli 2010).

Schumann, Olaf. "Bellah dan Wacana 'Civil Religion' di Indonesia" dalam Beyond Beief: Menemkan Kenbali Agama Esi-ese tentangA gama d Dunia Modkm, terj. Rudy Harisyah Alam. Jakarta: Paramadina, 2000.

Wahyudi, Chafid. "Misi Moral Agama yang Terabaikan", dalam DutaMasjarakat(28 D esember 2009.

Wahid, Abdurrahman. Prisma Penikiran Gus Dur. Yogjakarta: LKiS, 2000. . "Islam dan Masyarakat Bangsa", dalam Pesantren No. 3, Vol., VI. Jakarta: 1989. . Islam Kosmopolitan: Nilai-Nilai Indonesai dan Transformasi Kebudayaan. Jakarta: The Wahid Institute, 2007.

Zada, Khamani. Islam Radikal: Pergulatan O rmas-ormas Islam Garis Keras di Indonesia. Jakarta: Teraju, 2002. 